University of Nebraska - Lincoln

DigitalCommons@University of Nebraska-Lincoln

1927

\title{
The Etymology of an English Expletive
}

Louise Pound

Follow this and additional works at: https://digitalcommons.unl.edu/englishfacpubs

Part of the Comparative Literature Commons, English Language and Literature Commons, Modern Literature Commons, and the Reading and Language Commons

This Article is brought to you for free and open access by the English, Department of at DigitalCommons@University of Nebraska - Lincoln. It has been accepted for inclusion in Faculty Publications -Department of English by an authorized administrator of DigitalCommons@University of Nebraska - Lincoln. 


\title{
THE ETYMOLOGY OF AN ENGLISH EXPLETIVE
}

\author{
Louise Pound \\ UNIVERSITY OF NEBRASKA
}

Professor G. P. Krapp makes an attractive case for his derivation of darn, darned in the brief essay on this word in his recent The English Language in America. ${ }^{1}$ He discards the usual explanation that darn is a variant or minced form of $d a m n,{ }^{2}$ and believes that, although it now stands in intimate relation to damn, it had an independent origin. $\mathrm{He}$ takes as his starting point the Old English adjective dierne, 'secret,' Middle English derne, Elizabethan dern, ${ }^{3}$ and assumes a transition from a descriptive adjective or adverb to an imprecation. The adjective took on, he thinks, the form of a participial adjective, and thence developed verbal usage. Our occasional mild dern would then represent a more basic form than the commoner darn.

The earliest records of darn, darnation entered by lexicographers come from New England, and Dr. Krapp thinks that these forms are of New England Puritan origin. His last paragraph reads:

In brief then the explanation of darn, darned is that the word was originally Old English dierne which developed as an intensive adjective and adverb. As an adjective darn readily took on the form of a participial adjective, just as addle, originally an adjective became also addled, a participial adjective. From addled a finite verb was then formed, as 'to addle one's head over accounts'. So also from darned a verb darn was derived. As the New England social conscience was tender on this point of swearing it was the most natural thing in the world for the New Englander to secure the necessary relief which an imprecation affords by substituting the already familiar and inoffensive darn for the bolder but unequivocally profane word of the vocabulary.

Nevertheless, it is not easy to surrender the conviction that darn is no derivative of an adjective or adverb but is somehow to be asso-

1 Vol. I, 119-26.

2 Entered in the Oxford Dictionary, the Century, Weekley's Etymological Dictionary, etc.

${ }^{3}$ This is the adjective used by the American poet, Joseph Rodman Drake, in the tenth strophe of The Culprit Fay (1835):

'Through dreary beds of tangled fern

Through groves of nightshade dark and dern,' 
ciated from the first with damn, damnation. Dr. Krapp's etymology seems to me to be open to question for various reasons. For one thing, the old adjective dern seems an unlikely source for an expletive. Looking through Mary Crawford's English Interjections in the Fifteenth Century ${ }^{4}$ W. L. Ramsay's list in his edition of Skelton's Magnyfycence, ${ }^{5}$ E. C. Hills' Exclamations in American Speech, ${ }^{6} \mathrm{I}$ find exhibited in them no tendency for expletives to develop from adjectives and adverbs. The main sources for exclamations, when they are not arbitrary coinages, are verbs and nouns. Dr. Krapp's analogous word addle (originally an adjective, becoming addled a participial adjective and addle a finite verb), to be the perfect analogy that he needs to support his argument, should have become an expletive. It did not and probably never will.

Further, it is of importance, surely, to inquire how Dr. Krapp would relate darn the expletive to darn meaning 'mend.' The usual etymology of the latter word derives it from Middle English dierne, derne, and this seems a probable source for it. Are we then to think of the homophone verbs darn 'mend' and darn the expletive (both seventeenth-century $d \dddot{r} n$ ) as identical in origin but diverging in the last two hundred years. This seems hardly likely, and the early occurrences of the two words do not point toward it. Or are we to seek a new etymology for darn 'mend'? Assuredly the relationship of the two words should be scrutinized and explained before we appropriate the accepted derivation of the standard word for the dialect word.

The phonetic difficulties in the way of a derivation of darn from damn that are pointed out by Dr. Krapp do not seem insuperable if we go back to the period when the pronunciation of damned was dissyllabic. There is a simple and convincing way, however, in which the -rn of darn may be accounted for, and its development placed later than Colonial or even than Puritan times.

The earliest occurrence of darn cited by the Oxford Dictionary is from 1837-40. Haliburton has 'I guess they are pretty considerable darn fools'. ${ }^{7}$ Lowell has darned in the Biglow Papers ${ }^{8}$ and Dickens makes an American say darn in Martin Chuzzlewit, 'We don't mind them if they come to us in newspapers, but darn your books'. ${ }^{9}$ There is no evidence

\footnotetext{
4 University of Nebraska Studies 13. 361-405.

${ }^{5}$ Early English Text Society, Extra Series 98, p. 83.

${ }^{6}$ Dialect Notes 5. 7. 253-84 (1924).

${ }^{7}$ T. C. Haliburton, The Clockmaker, 1837-1840 (1862), p. 29.

8 'You darned old fool.' 1. 145 (1845).

${ }^{9} 1843-1844$. Ch. xvi.
} 
that requires us to go back to Puritan days. Darn, so far as it may be documented, sounds like a Yankee rather than a Puritan form. It gained currency rapidly in the first half of the nineteenth century, and by the second half of the century it is in general dialectal and colloquial use, not only for America but for England and Scotland.

The aphetic adjective tarnal, used to express abhorrence or disparagement and then merely as an intensive, is familiar to American readers from Lowell's Biglow Papers. ${ }^{10}$ It was used in the late eighteenth century. The Oxford Dictionary cites from 1790, 'The snarl-headed curs fell akicking and cursing of me at such a tarnal rate that. . . . I was glad to take to my heels'. ${ }^{11}$ Probably tarnal derived its original force as an expression of execration from the phrase 'eternal (etarnal) damnation,' out of which came the form tarnation, a sort of amalgam of tarnal and damnation. The first instance of tarnation noted in the Oxford Dictionary comes, like tarnal, from 1790, 'What the rattle makes you look so tarnation glum', ${ }^{12}$ and the next from 1801, 'The Americans say, Tarnation seize me or swamp me, if I don't do this or that'. ${ }^{13}$ Significant also, for our purpose, is the sentence from the New England Magazine (Boston, 1832), "We have "tarnation" and "darnation" for damnation'. ${ }^{14}$ By the last half of the century tarnation is in general use, not only in America but in England, Scotland, Ireland. Mrs. Carlyle, for example, writes of 'tarnation folly'.15 Parallels would be lacking for the voicing for phonetic reasons of tarnation (with its $r$ from tarnal) to darnation, but an explanation may be found in contamination. The influence of damnation itself, after tarnation had been formed, would explain darnation, the form with initial $d$ that was eventually to be the more popular form. From darnation it is easy to derive the verb darn and the participial adjective darned.

The earliest citations in the Oxford Dictionary of tarnal and tarnation take us into the eighteenth century. They antedate by some decades the appearance of darn, which is first adduced from Haliburton's Sam Slick, 1837-40; and this may well be taken into account. Nothing very decisive may be learned from the order of their appearance, for all

10 'I darsn't skeer the tarnal thing fer fear he'd run away with it.' 2.1.72.

$11 \mathrm{R}$, Tyler. The Contrast 2. 2.39 (1837).

12 Ibid. 5. 1. 88. I am indebted to Professor T. A. Knott for the suggestion that the relation of tarnation and darn be examined.

${ }^{13} \mathrm{G}$. Hanger, Life 2. 151.

143.380.

${ }^{15}$ Letters, 1857 (1883) 11. 329. 
come into view within a half-century. It is clear, however, that in the association of tarnal and damnation may be found another and an adequate explanation of the $r n$ of $d a r n$, the sounds viewed as a stumbling block by Dr. Krapp and underlying his advocacy of a derivation from the old adjective dern. It is clear also that we need not go back to Old or Middle English, or to the Elizabethans, or even to the Puritans, if we accept, as explaining our popular expletive, the sequence: tarnal damnation, tarnation, darnation (with its $d$ from damnation), darn, darned. By this route we are brought back to an association from the first of darn and damn. But we proceed from an aphetic adjective and an amalgam-noun expletive, and we move forward the origin of the expression to a period nearer to our own. 